years; "Work Sampling using Extended Observations", by E. N. Corlett and R. H. Hollier, describing 'snap sampling' as applied to estimations of proportions of time spent in activities by operators and machines, but with an extended technique to provide idle time distributions, and the method involved; "Mechanics of Chip-breakers", by T. L. Subramanian and A. Bhattacharyya, deals with the problem of chip disposal now more acute with the introduction of high-speed carbide and ceramic tools, and presents a physical explanation of behaviours of the cutting variables encountered; W. A. Morcos contributes an article on the complex problem of "Interchangeability of Screw Threads: a Study of the Effective Diameter Equivalent of Flank Angle Errors for a Basic Taper Thread", with appropriate mathematical treatment and new methods of determination; a paper on "Classification of Pacing", by K. F. H. Murrell, explains the part played by tolerance in the classification and the relationship between tolerance and machine rate. With each contribution an appropriate synopsis in both French and German is included.

\section{A. P. Sloan Foundation}

THE report of the A. P. Sloan Foundation for the two years 1963-64 records commitments authorized by the Trustees of 30.4 million dollars. In support of basic scientific research, 5 million dollars went to the Massachusetts Institute of Technology to establish a special institutional research fund, and 1 million dollars to four mid-continent universities to strengthen their science facilitios and teaching. The level of expenditure in the Foundation's fellowship programme for basic research in the physical sciences was increased from $1 \cdot 2$ million dollars to 1.4 million dollars, beginning in 1965 . For the academic year 1963-64 there were 144 Sloan Research Fellows in 49 institutions in the United States and in Canada, compared with 155 in 48 institutions in September 1964. A grant of 1 million dollars was authorized for the new Mathematics Centre at Stanford University and one of 5 million dollars for Massachusetts Institute of 'Technology to establish a pioneering programme of continuing education for experienced engineers. Virtually all the Foundation's grants for cancer research (totalling 1.4 million dollars) went to the Sloane-Kettering Institute for Cancer Research in New York and to affiliated programmes; however, grants were also made for research in glaucoma and ureitis and an initial grant for a programme of research in otology. The Sloane National Scholarship Program now embraces 45 universities and colleges and totals 1.28 million dollars: a special grant of 500,000 dollars was made to the United Negro College Fund in 1963, as well as 200,000 dollars to other projects for strengthening educational opportunities for Negro students. A grant of 1 million dollars was made to Stanford University to complete a new Centre for its Graduate School of Business, and other grants in the same field were to the Columbia University Graduate School of Business, the Tuck School of Business Administration of Dartmouth College, and the Sloan School of Management of the Massachusetts Institute of Technology. Grants for economic research and education (mainly to the National Bureau of Economic Research) exceeded 1 million dollars and commitments for improving the public understanding of science totalled 275,000 dollars. In June 1963 a grant of 100,000 dollars was made to the United States Churchill Foundation for scholarships and fellow. ships.

\section{Education in Forestry}

UNDER the title Education in British Forestry a report of the fifth discussion meeting organized by the Society of Foresters of Great Britain has been issued as a supple. ment of the Society's journal, Forestry (Pp. 74. London: Oxford University Press, 1965. 78. 6d.). The discussion was held at Cirencester during January 8-10, 1965, and the three sessions dealt with the education of foresters; the education of forest officers; and with forestry education for the wider field. Besides Prof. M. V. Laurie's opening address and the text of the ten papers contributed, the report includes summaries of the discussion in each session and Mr. J. J. Lawrie's elosing remarks in which he referred to responsibilities towards Voluntary Service Overseas and to the opportunity afforded by the conference, "The Countryside in 1970". There was some frank criticism of British forestry education below university level and a resolution was passed recommending the Council of the Association, in co-operation with the Forestry Commission and other interested bodies, to investigate the establishment of institutions suited to both State and other forestry interests. At the universitylevel the meeting was impressed by advances in recent years, by the scope of present curricula, and by the lively outlook.

\section{Scientific Societies in India}

A Survey of Scientific Societies in India, by A. Rahman, N. Sen and N. R. Rajagopal of the Survey and Planning of Scientific Research Unit, has been published by the Council of Scientific and Industrial Research, New Delhi (Pp. 40. New Delhi: Council of Scientific and Industrial Research, 1965). Data were collected on the organization and role of such societies with the view of correlating them with the scientific and technological development of the country. Prior to 1930 there were few such societies and of the 27 listed 22 were established for specialized fields, 10 being concerned with engineering and technology. During 1931-50 the number of societies increased three-fold in the physical sciences and in the medical and biological sciences, and doubled in engineering and technology; this is attributed largely to the development of a base for research in the country. From 1951 onwards the trend to establish more scientific societies continued to increase, and is marked by the establishment of such highly specialized societies as the Indian Cancer Society, the Indian Society of Haematology, the Indian Society for Helminthology, the Institute of Telecommunication Engineers, the Indian Society for Rayon Technologists, the Indian Leather Technologists Association and the Institute of Information Scientists. The societies are heavily concentrated in cities like Calcutta, New Delhi, Bombay, Bangalore and Madras, where 118 out of 150 are located and only 54 per cent have a membership of 100 to 500. Only the Institution of Engineers, India, with 42,887 , has more than 5,000 members. Almost 90 per cent issue periodicals and more than 31 per cent receive financial support from the Central Government, about 30 per cent from State Governments and about 18 per cent from industry. Of the 103 societies giving figures for income and expenditure, about 36 per cent had annual incomes by 1962 of $10,000-50,000$ Rs., and some 7 per cent an income of less than $1,000 \mathrm{Rs}$. The total membership of 115 societies out of the 150 is about 95,000 compared with a total of postgraduate scientists, medical graduates and engineering graduates of about 188,000 .

\section{Journal of Labelled Compounds}

THE first number of the new quarterly Journal of Labelled Compounds contains eight original contributions, one German, three French and four English, with English summaries, together with a section containing abstracts of 67 papers dealing with the synthesis of labelled compounds and related compounds (1, No. 1, January-March, 1965. Pp. 1-92. Brussels: Presses Académiques Européennes, 1965. Annuol subscription: B.F.1.250; 25 dollars). The editor of the Journal is J. Sirchis of Euratom (Brussels) and there is an editorial board consisting of twenty members. The abstractor is H. Dworschak of the Information and Documentation Centre, Euratom. Two of the 